DOI https://doi.org/10.30525/978-9934-26-000-1-7

\title{
УНІВЕРСАЛЬНА МОДЕЛЬ ВЕРСТКИ ТЕЛЕВІЗІЙНИХ НОВИН І ЇЇ СТРУКТУРА
}

\author{
Теленков Д. В. \\ аспірант кафедри видавничої справи та редагування \\ Інститут журналістики Київського національного університету \\ імені Тараса Шевченка \\ м. Київ, Украӥна
}

Поняття «модель верстки телевізійних новин» на сьогодні не здобуло поширення в науковому дискурсі, проте вживається, радше інтуїтивно, в журналістській практиці.

Верстка новинних випусків різних телеканалів, хоч і має відмінності, може бути зведеною до принципового підходу, інтелектуальної конструкції - структурної моделі телеверстки.

Пропоную авторське визначення: модель верстки теленовин - це типова сукупність принципів, способів, прийомів, що застосовує випускова група, формуючи випуски теленовин, відповідно до редакиійної політики, особливостей глядацької аудиторії, поточної суспільної ситуаиії, часу виходу в ефір тощзо. Як послідовний підхід до організаиії контенту, модель верстки визначає основу «порядку денного», інформаиійні акцеетти, тематизує трансльовану картину світу.

Розроблена структурна модель телеверстки належить до абстрактних систем, адже йдеться про систему теоретико-методологічного характеру, на основі котрої можливо описувати і загальні, і специфічні властивості організаційної структури теленовин, зв'язки між елементами цілісного новинного випуску, його інтеграцію в загальну концепцію телеканалу як складного контент-об'єкта.

Моделювання - складне, трудомістке та відповідальне наукове завдання. Іноді дослідження за допомогою моделей $є$ єдино можливим способом експериментального вивчення технологічних процесів. Так, процеси, котрі тривають роками, можна оперативно вивчати на моделях. I навпаки, швидкоплинні процеси не раз вивчаються на моделях протягом тривалішого часу. Крім того, до моделювання звертаються тоді, коли досліджувати реальні об’єкти 3 усією сукупністю їхніх властивостей недоцільно, незручно або неможливо. Предметний аналіз структури теленовин кожного українського телеканалу може розтягнутися на десятиліття. Саме моделювання й структурна модель можуть дати оперативніші відповіді, всеохопніше розуміння феномену теленовин. 
Пропоную універсальну модель телеверстки, котра, вірогідно, не дає відповіді на всі запитання телевиробництва, однак узагальнює, підсумовує практики, передає функціонально найхарактерніші властивості.

Звісно, будь-яка модель фіксує наявний рівень пізнання. Тож пропонована модель верстки теленовин апріорі може оновлюватися разом із самою телеверсткою.

\section{Структура моделі телевізійної верстки.}

Сутнісно й функціонально модель верстки теленовин - комунікаційна технологія. Стверджуючи це, ми розвиваємо сформовану в теорію соціальних комунікацій парадигму.

Д. Мак-Квейл у теорії «порядку денного» вбачав технологію масової комунікації. Його концептуальне тлумачення новинного дискурсу таке: «інтерес до новини (емпіричні уявлення про те, що цікавить аудиторію) - критерії новини - подія - повідомлення (результат аналізу інтересів громадськості та подій, які сюди вписуються)» [1, с. 537].

Над розвитком цієї теорії згодом працювали Е. Роджерсі та Дж. Діаринг.

Явище «agenta setting» у них еволюціонувало до «agenta building»: замість встановлення «порядку денного» - його побудова. Дослідники проаналізували, як працює «порядок денний» i виробили чотири чинники, які його формують: «політичний (за способом подачі теми стоять передусім політичні мотиви), медійний (його встановлюють ЗМI, зокрема, конкуренти), публічний (наскільки на ту чи іншу тему $\epsilon$ суспільний запит), корпоративний (наявність джерел у конкретного ЗМІ, його географічне розташування, фаховість конкретних кореспондентів тощо)» [2, с. 555-594].

Структура пропонованої моделі телевізійної верстки відображає устрій новинних випусків. Адже будь-яка новинна програма- це складний симбіоз інформації для мовлення. Вона містить сукупність матеріалів різної форми, характеру, жанрів. Новини повинні виглядати цілісно, логічно, інформація має витікати одна з одної, навіть якщо це протилежні теми.

Розглянувши випуски новин як структури, що співвіднесені із суспільною реальністю, їх змодельовано: 1) виокремлено тематику, форми iii представлення, застосовані прийоми тощо; відстежено закономірності; 3) узагальнено їх - 4) показано вузлові складники й зв'язки між ними. Розроблена таким чином принципова структурна модель телевізійної верстки представлена в схемі.

Схема

\section{Структура моделі телевізійної верстки}

Принцити відбору

та ранжування тем
Способи

представ.лення

інформації
Ефірні прийоми 
Отже, виокремлено такі складники моделі телевізійної верстки:

1) принципи відбору та ранжування тем - послідовність тем і сюжетів, почерговість тематичних блоків, тематичне фокусування на певній проблематиці тощо;

2) способи представлення інформації - вибір жанрових форм матеріалів, знакової форми інформації, форматування випусків залежно від технічних можливостей, часу виходу в ефір, вибір стилістичномовного оформлення, створення образу ведучого;

3) ефірні прийоми - драматургічне відпрацювання окремих сюжетів і поєднання їх у цілісний випуск.

Цілісність новинного випуску досягається за рахунок верстки попереднього ескізу майбутньої інформаційної програми, за яким працює випускова група та журналісти. На кожному каналі таких груп кілька - це виробничо-творчі підрозділи редакції новин, які збирають, опрацьовують і видають в ефір матеріали (традиційно поділ на випускові групи відбувається залежно від блоку мовлення - ранкова, денна, вечірня, нічна). Тож в ідеальному варіанті виокремлені аспекти моделі функціонують синергетично, що забезпечує повноцінний i якісний випуск телевізійних новин.

\section{Література:}

1. Мак-Квейл Д. Теорія масової комунікації Львів : Літопис, 2010. -537 c.

2. Rogers E., Dearing J. Agenda-setting research: Where has it been, w here is it going? Communication Year book. - 1988. - Vol. 11. - P. 555-594. 